\title{
Partisipasi Warga terhadap Sistem Informasi Desa
}

\author{
Fadjarini Sulistyowati /MC. Candra Rusmala Dibyorin \\ Program Studi Ilmu Komunikasi STPMD "APMD” Yogyakarta J1. Timoho 317 \\ Yogyakarta Telp. (0274) 561971 \\ dzarbela@yahoo.co.id
}

\begin{abstract}
The existence of village information service using technology is one of the villages effort to achieve transparency of information to various parties. The existence of information systems make citizens' access to get information more widely and easily. The important thing in this system is about the participation of the villagers. This research was conducted in Terong village, Dlingo - Bantul with the assumption that the information system in this village is one of the applications which afforded by LSM Combine Resource Institute participatory. The method of the research uses a qualitative descriptive study. Target of the research is social life or society as a whole or a whole entity. A technique to obtain data is from observations, focus group discussions and interviews with informants who are considered to be related to the information system of the village. The data analysis are using interactive analysis model which developed by Miles and Hubermann. The result showed that: 1. Public participation to the existence of village information system started when the system is put in place. 2. The emergence of community participation due to the great synergy between village officials, LSM and communities. 3. Participation of community should be increased by controlling the presence of village information system for the public.
\end{abstract}

Key words: village information system, participation, community

\begin{abstract}
Abstrak
Teknologi menjadi bagian dari upaya untuk memudahkan pendataan desa. Salah satunya dari pemanfaatan teknologi di desa adalah sistem informasi desa yang dikembangkan oleh Combine Resource Institution (CRI) di Desa Terong Kecamatan Dlingo Kabupaten Bantul. Dengan adanya Sistem Informasi Desa, keberadaan dan kelengkapan data di desa dapat didokumentasikan dengan lebih baik. Penelitian ini bertujuan mendeskripsikan Sistem Informasi Desa di Desa Terong Kecamatan Dlingo Kabupaten Bantul. Metode penelitian menggunakan Metode penelitian yang dipakai adalah deskriptif kualitatif, yang menjadi sasaran penelitian adalah kehidupan sosial atau masyarakat sebagai satu kesatuan atau sebuah kesatuan yang menyeluruh. Teknik memperoleh data didapat dari: observasi, Fokus Group Discussion (FGD) dan wawancara terhadap informan yang dianggap memiliki keterkaitan dengan sistem informasi desa. Teknik analisis data yang digunakan adalah model analisa interaktif yang dikembangkan oleh Miles dan Hubermann. Dari hasil penelitian didapatkan:

1) Partisipasi masyarakat terhadap keberadaan sistem informasi desa diawali pada saat sistem ini diberlakukan; 2) Kemunculan partisipasi masyarakat karena adanya sinergi yang antara aparat desa, LSM dan masyarakat; 3) Partisipasi masyarakat harus terus dtingkatkan dengan upaya mengontrol keberadaan sistem informasi desa bagi masyarakat.
\end{abstract}

Kata kunci: sistem informasi desa, partisipasi, masyarakat 


\section{Pendahuluan}

Perkembangan teknologi saat ini berkembang sangat pesat. Berbagai program teknologi informasi dan komunikasi semakin canggih dan memudahkan manusia dalam berbagai kegiatan. Saat ini sesuai dengan konsepMcLuhan pada tahun 1960-andalam bukunya Understanding Medi: Extension of A Man telah terjadi proses penghilangan jarak, ruang dan tempat yang awalnya dianggap jauh menjadi seolah-olah berada di dekat kita. Konsep global village inilah yang dianggap sebagai era globalisasi. Saat ini dengan kemajuan teknologi informasi memungkinkan semua orang berbagi informasi dan menjalin jejaring melalui dunia maya.

Prediksi McLuhan yang dulunya hanya bisa dibayangkan sekarang sudah terjadi di depan kita. Perkembangan teknologi informasi mengakibatkan masyarakat terhubung dengan berbagai koneksimedia. Berbagaifasilitashanphone, komputer dan fasilitas media lainnya silih berganti tiap tahun. Masyarakat mulai familiar dengan penggunaan berbagai teknologi media untuk menjalin interaksi dan meninggalkan media tatap muka .

Perkembangan teknologi bukan hanya dimanfaatkan oleh masyarakat kota namun juga oleh masyarakat pedesaan. Masyarakat desa sudah tidak asing lagi dengan penggunaan telepon seluler, internet dan lain-lain. Walaupun belum semua wilayah di Indonesia dapat memanfaatkan teknologi informasi namun dengan seiring waktu berjalan niscaya teknologi informasi akan sangat cepat berkembang hingga pelosok wilayah Indonesia.

Pemerintah melalui Depkominfo pun sudah mulai mencanangkan beberapa kebijakan dalam rangka mewujudkan era informasi salah satunya adalah mengembangkan program desa informasi. Melalui program ini, diharapkan dapat mencerdaskan kehidupan bangsa dan memajukan pembangunan perekonomian warga masyarakat yang berada di wilayah perbatasan dengan mengoptimalkan penggunaan teknologi informasi dan telekomunikasi, yang dicanangkan sejak tahun 2009 (S. Bayu Wahyono, 2011: 128). Untuk mewujudkan program desa informasi, pemerintah melalui Depkominfo mengembangkan program internet di desa sehingga saat ini bisa dikatakan internet telah masuk ke berbagai desa khususnya di Jawa. Beberapa program Depkominfo yakni Desa Berdering, Desa Pinter, dan Pusat Layanan Internet Kecamatan, upaya yang sudah dilakukan sejak tahun 2010 . Target adanya internet masuk desa, maka wilayah pelosok, yang selama ini selalu tertinggal mendapatkan informasi tak akan lagi mengalami hal itu.

Berdasarkan data dari Depkominfo, pemerintah melalui Depkominfo mengeluarkan beberapa program dalam rangka memanfaatkan perkembangan teknologi informasi untuk pengembangan informasi di desa misalnya dengan program desa perintis (2005),terhubungnya desa denganfasilitas telekomunikasi; desa berdering terpadu (2010); 3) desa online (2015), peningkatan kualitas dan kuantitas layanan hingga 10 sst untuk 1 desa, dilanjutkan dengan penyediaan barang akses internet; 4) desa multimedia (2020), pemanfaatan TIK sudah menjadi kebutuhan masyarakat desa dalam aktivitas sehari-hari dan menjadikan TIK sebagai sarana untuk meningkatkan kegiatan perekonomian di desa. 
Beberapa LSM yang memiliki keberpihakan terhadap media informasi juga ikut mendorong perkembangan teknologi informasi di tingkat pedesaan. Salah satunya yang dipelopori oleh Combine Resource Institution (CRI), yakni lembaga yang mendukung pengembangan jaringan informasi berbasis komunitas. LSM yang beranggotakan anak-anak muda yang giat menggerakkan masyarakat dalam mengelola teknologi informasi di wilayahnya untuk menjadi ruang berbagi informasi bagi komunitas tersebut.

Salah satu yang dikembangkan oleh CRI adalah sistem informasi desa (SID) yakni informasi yang diimplementasikan melalui prangkat teknologi informasi dan aplikasi perangkat lunak yang dioperasikan oleh perangkat desa. Sistem informasi ini dibangun dengan berbasis komputer dan web sehingga informasi ini dapat diakses oleh warga. Lisensi SID dikembangkan dalam platform sistem perangkat lunak bebas dan terbuka (free and open source software) yang berarti dapat digunaka, disalin, didistribusikan, ditingkatkan kinerjanya, dimodifikasi sesuai dengan kebutuhan (Wilhem Wau, 2012).

Saat ini CRI telah banyak mengembangkan SID di desa-desa beberapa wilayah Indonesia, terutama di Daerah Istimewa Yogyakarta, provinsi Jawa Barat, Nusatenggara Barat dan Nusa tenggara Timur hingga Papua. Salah satu tujuannya adalah untuk meningkatkan akses masyarakat terhadap informasi.

Dengan adanya penggunaan teknologi informasi melalui internet memberikan manfaat yang cukup besar. Manfaat yang dirasakan oleh desa misalnya dalammembantumengarsipkan data -data desa. Data desa yang banyak dimanfaatkan oleh masyarakat yang sering kita dengar adalah monografi desa. Monografi desa adalah unit terkecil dari monografi kecamatan dan selanjutnya menjadi bahan dasar dari sebuah monografi kabupaten. Monografi ini tentunya menjadi sumber data yang sangat penting untuk membangun kebijakaan desa. Namun seringkali dengan pengarsipan data yang manual seperti data monografi desa yang ditempel di dinding, keakuratan datanya sulit untuk dipertanggungjawabkan karena seringkali update data tidak mudah dilakukan.

Padahal peran desa dalam pendataan penduduk kerap menimbulkan masalah krusial, misalnya menyangkut penetapan warga masyarakat yang berhak menerima bantuan/subsidi dari pemerintah. Fenomena penyaluran dana kompensasi bahan bakar minyak (BBM), bantuan beras untuk rakyat miskin (Raskin), dan jaminan kesehatan masyarakat (Jamkesmas) yang salah sasaran tidak akan terjadi jika pemerintah desa memiliki data profil warganya yang akurat dan mutakhir (up-to-date). Data juga menjadi informasi yang penting bagi masyarakat sendiri untuk melakukan upaya membangun kemandirian desa.

Untuk era saat ini teknologi informasi penting untuk dimanfaatkan untuk berbagai kepentingan termasuk memberikan layanan informasi desa. Adanya layanan informasi desa dengan memanfaatkan teknologi merupakan salah satu upaya desa untuk mewujudkan transparansi informasi ke berbagai pihak. Dengan demikian, masyarakat dapat ikut serta untuk mengetahui serta mengawasi kebijakan desa, serta ikut berperan aktif dalam kegiatan-kegiatan desa. Sistem informasi desa akan memberikan akses publik akan informasi sesuai dengan UU 
Keterbukaan Informasi Publik yakni UU Nomor 14/ 2008.

Selain itu, pentingnya informasi yang dapat terakses luas juga dilakukan untuk pengembangan potensi desa sendiri. Masyarakat dari desa di daerah lain akan dapat mengakses informasi tersebut. Bahkan dengan adanya sistem informasi ini akan memungkinkan terjalinnya jejaring desa dengan berbagai pihak yang kemanfaatnnya untuk pengembangan desa.

Ada berbagai model aplikasi informasi yang dibangun di desa baik yang merupakan aplikasi turunan dari pemerintah yang berupa sistem informasi profil desa dan kelurahan yang disampaikan oleh Departemen Dalam Negeri pada tahun 2012. Kelemahan dari data Profil Desa yang disampaikan oleh Departemen Dalam Negeri menurut Sutoro Eko (2012: vii), pertama profil desa tidak cukup memadai sebagai instrumen dan ruang akuntabilitas publik yang menjadi modal bagi demokrasi desa. Kedua, profil desa dari sisi teknis kurang memadai karena yang dapat mengisi/ menginput data hanyalah perangkat desa.

Selanjutnya, sistem informasi desa yang difasilitasi oleh Combine Resource Institution (CRI). Sistem informasi desa merupakan rangkaian/sistem yang bertujuan untuk mengelola sumber daya komunitas, selain itu merupakan aplikasi yang membantu pemerintahan desa dalam mendokumentasikan berbagai data milik desa. Contoh desa yang cukup berhasil dalam mengunakan aplikasi ini adalah Desa Terong Kecamatan Dlingo Kabupaten Bantul dan Desa Nglegi Kecamatan Patuk Kabupaten Gunungkidul (2012: 56).

Keberadaan teknologi informasi dalam membantu layanan masyarakat di pedesaan sangatlah penting namun hal itu tidak akan berarti tanpa adanya partisipasi masyarakat. Dengan adanya partisipasi warga terhadap sistem informasi tersebut maka target utama adanya keberadaan aplikasi untuk memberikan kemajuan dan akses informasi yang lebih luas bagi masyarakat akan tercapai. Selain itu, partisipasi warga akan memberikan dukungan untuk mengawasi transparansi informasi. Tanpa adanya partisipasi masyarakat maka sistem informasi hanyalah menjadi perangkat aparat desa yang kurang bermakna karena masyarakat merasa tidak memiliki.

Penelitian yang dilakukan di Desa Terong Kecamatan Dlingo untuk mengetahui partisipasi masyarakat terhadap sistem informasi desa. Bagaimana bentuk-bentuk partisipasi masyarakat terhadap sistem informasi desa yang diprogramkan oleh Combine Resource Institution? CRIselamainimenyampaikan dalam berbagai seminar bahwa sistem informasi desa dikemas sebagai program yang mengharuskan adanya partisipasi masyarakat. Penelitian ini membatasi pada partisipasi warga terhadap sistem informasi desa karena partisipasi warga merupakan kajian penting dalam program yang berkaitan dengan masyarakat. Dengan adanya penelitian ini memberi masukan pada berbagai pihak dalam upaya penyebarluasan sistem informasi desa ke berbagai desa di Indonesia.

\section{Metode Penelitian}

Pendekatan yang digunakan dalam penelitian ini adalah deskriptif kualitatif yaitu suatu metode untuk memaparkan serta menjelaskan kegiatan atau objek yang diteliti yang berkaitan dengan 
pengkajian fenomena secara lebih rinci atau membedakannya dengan fenomena yang lain(Denzin dan Lincoln, 2009 :223).

Upaya untuk memperoleh data di lapangan dilakukan dengan: 1) Observasi/ pengamatan terhadap manfaat dan peranan sistem informasi Desa Terong Kecamatan Dlingo Kabupaten Bantul dalam mendukung berbagai kegiatan dan kebijakan pemerintahan desa; 2) MelaksanakanFokus Group Discussion (FGD) terhadap warga melalui kegiatankegiatan formal dan informal desa/ pedukuhan seperti: Karang Taruna, BPD dan Aparat Desa. Dari kegiatan FGD akan diambil informan untuk diwawancarai lebih mendalam; 3) Wawancara mendalam kepada informan yang diambil dari warga yang telah ikut kegiatan FGD. Informan ini meliputi aparat desa, dan pemuka masyarakat. Teknik penentuan informan dalam penelitian ini menggunakan teknik purposivesampling (sampling bertujuan), yakni, menentukan sampel dengan pertimbangan tertentu yakni mereka yang dipandang memiliki kapabilitas dan kompeten untuk memberikan data secara maksimal. Sedangkan pengambilan sampelnya dengan teknik snowball sampling, peneliti memilih informan secara berantai. Teknik analisis data yang digunakan adalah model analisa interaktif yang dikembangkan oleh Miles dan Hubermann (dalam Sutopo: 2006):1) Pengumpulan data; 2) Reduksi data; 3) Penyajian data 4) Penarikan simpulan dan verifikasi.

\section{Hasil Penelitian dan Pembahasan}

Pemerintah Desa Terong, Kecamatan Dlingo, Bantul menerapkan program Sistem Informasi Desa (SID) sejak tahun 2006. Inovasi ini muncul secara tak sengaja yakni ketika aparat desa menyadari bahwa adanya bencana dapat memusnahkan data dan dokumen data dalam waktu yang singkat. Gempa bumi di Yogyakarta (2006) menyebabkan lemari data milik desa roboh sehingga datadata desa pun rusak. Dari situ mereka bermimpi memiliki sistem barcode model minimarket yang dapat dimanfaatkan untuk mendokumentasikan data desa lebih efektif dan tidak mudah rusak karena bencana.Keinginan masyarakat ini kemudian dikemukakan oleh Bp. Lurah pada saat itu Bp. Sudirman kepada Combine Resource Institution (CRI).

\section{Partisipasi Warga dan Sistem Informasi Desa}

Keberadaan sistem informasi desa di Desa Terong didorong dari keinginan aparat desa yang merasa kebingungan karena desa yang tidak memiliki arsip data penduduk setelah terjadinya gempa di DIY pada tahun 2006. Pada saat yang bersamaan Combine Resource Institution (CRI) sedang menggarap radio komunitas di desa tersebut. CRI mencoba untuk mewujudkan "mimpi" desa tersebut dalam program Sistem Informasi Desa (SID). Program sistem informasi desa pada hakikatnya merupakan tiga kemasan program yakni radio komunitas, program SID yang dapat berfungsi membantu pelayanan termasuk adanya sms centre atau sms Gateway dan website http://www.terong-bantul.web.id.

Dengan demikian, kemunculan program memang berasal dari keinginan masyarakat desa yang dimotori oleh Bapak Lurah. CRI berperan sebagai fasilitator untuk membantu mewujudkan. Hal ini sesuai dengan konsep partisipasi konsep partisipasi dariBritha Mikkelsen terutama dalam konsep yang ketiga bahwapartisipasi merupakan proses yang aktif, yang mengandung arti bahwa orang 
atau kelompok yang terkait mengambil inisiatif dan menggunakan kebebasannya untuk melakukan hal itu.

Proses awal pendirian SID ini dilakukan dengan sukarela dan gotong royong antara warga masyarakat dan CRI. Para pemuda Karang Taruna ikut ambil bagian dalam mensosialisasikan ke semua elemen di masyarakat. Sosialisasi dilakukan beberapa kali dengan mengikutsertakan budaya lokal masyarakat seperti adanya gelar budaya desa, pentas wayang kulit, Jathilan dan lain-lain. Selain itu, keberadaan radio komunitas desa juga ikut membantu mensosialisasikan SID. Hal ini tentunya sesuai dengan konsep partisipasi dari Britha Mikkelsen yang ke lima dan enam yakni, partisipasi merupakan keterlibatan sukarela oleh masyarakat dalam perubahan yang ditentukannya sendiri dan partisipasi adalah keterlibatan masyarakat dalam pembangunan diri, kehidupan dan lingkungan.

Selanjutnya partisipasi dari masyarakat ini tampak dalam pengisian data SID. Kelompok pemuda dan berbagai elemen dari masyarakat desa ikut membantu melakukan pendataan penduduk yang dilakukan dengan mendatangi warga dari rumah ke rumah. Pendataan yang dilakukan dari rumah ke rumah ini dalam upaya mendapatkan data yang valid dan pengisian lembar kuesioner pun didampingi dari pihak Karang Taruna dan CRI. Setelah itu, memasukkan data ke komputer yang dilakukan oleh aparat desa bersama dengan Pemuda dan Pemudi Karang Taruna serta bantuan tenaga dari CRI. Proses pendataan berlangsung cukup lama yakni hingga tiga bulan. Antusias masyarakat terhadap program ini juga tampak dari keterbukaan mereka untuk mengisikan data tersebut sehingga proses pendataan data menjadi valid.

Partisipasi masyarakat dalam pembentukan dan pengisian data SID yang dimunculkan oleh aparat desa, tokoh masyarakat dan CRI ini sesuai dengan "tangga partisipasi yang dimunculkanoleh Sherry Arnstein (2001: 23-24). Tangga ini memperlihatkan berbagai cara organisasi menyikapi suatu kegiatan misalnya bagaimana pemerintah daerah dapat melibatkan warganya:

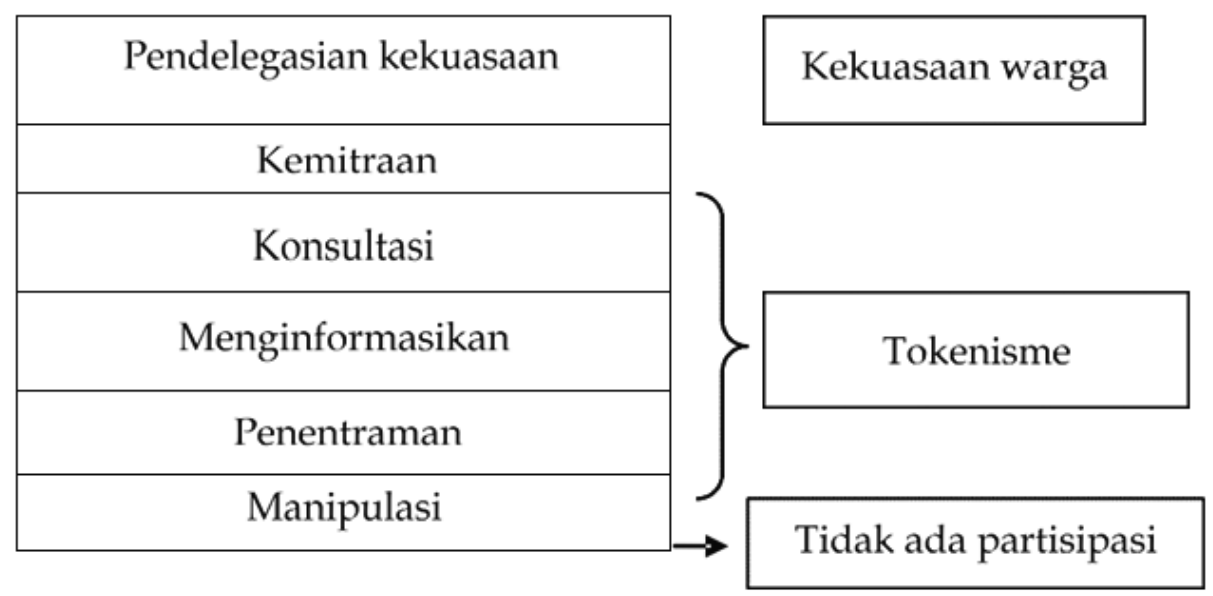

Gambar 1: Tangga Partisipasi 
Partisipasi menurut Arnstein adalah bagaimana masyarakat dapat terlibat dalam perubahan sosial yang memungkinkan mereka mendapatkan bagian keuntungan dari kelompok yang berpengaruh. Arnstein telah membuat delapan tangga partisipasi. Untuk tangga pertama disebut manipulasi dan kedua penentraman. Di tangga pertama dan kedua menurut Arnstein tidak aka nada partisipasi. Selanjutnya, tangga ketiga, menyampaikan informasi. Tangga Keempat, konsultasi dan kelima kemitraan. Kategori pada tangga ketiga hingga lima ini disebut tingkat tokenisme. Tokenisme yaitu suatu tingkatan peran serta di mana masyarakat didengar dan diperkenankan berpendapat, tetapi mereka tidak memiliki kemampuan untuk mendapatkan jaminan bahwa pandangan mereka akan dipertimbangkan oleh pemegang keputusan.

Program SID dimunculkan dengan meniadakan manipulasi masyarakat. Hal yang terjadi adalah upaya menginformasikan terlebih dahulu, hingga mengajak masyakata untuk ikut terlibat dalam pengisian SID. Hal ini dapat dikatakan pelaksanaan SID di Desa Terong sudah sampai dalam tahap tokenisme. Masyarakat diajak bicara, dan dapat menyampaikan kritikan. Bahkan menurut CRI, layanan program dalam SID dimunculkan sesuai dengan permintaan masyarakat.

\section{SID merupakan Sinergi antara Aparat Desa, Masyarakat dan CRI}

Partisipasi yang dilaksanakan masyarakat Desa Terong bukan didorong oleh kepentingan LSM yang dalam hal ini adalah CRI. Seperti yang disampaikan di awal, keberadaan SID atas inisiatif aparat desa, berarti desa membutuhkan program ini. Kedua, sosialisasi kepada masyarakat dilakukan dalam rangka menginformasikan fungsi dan peran SID bagi desa dan manfaatnya akan dirasakan masyarakat. CRI dalam program ini berperan sebagai fasilitator, dengan demikian partisipasi ini adalah murni dari desa. Hal ini sesuai dengan konsep Hamidjoyo (2000) tentang partisipasi murni.

SID menjadi program bersama yang merupakan sinergi antara aparat desa, masyarak dan CRI. Hal ini tampak dalam upaya masyarakat untuk menjaga keberlangsungan program SID sampai saat ini. Pihak aparat desa cukup serius dalam menjaga keberlangsungan program SID. Kepala desa yang baru menggantikan kepala desa yang lama cukup memahami program SID ini berarti ada upaya untuk mewariskan keberadaaan SID. Partisipasi dari masyarakat di Desa Terong bukanlah bersifat mobilisasi seperti penelitian yang dilakukan Fajarini Sulistyowati, Theodorus Wuryantono, dan Dian Astuti (2005) sebelumnya di Desa Timbulharjo karena suatu program yang datangnya dari elit desa hanya akan dipahami oleh elit desa bukan semua lapisan masyarakat. Kegiatan SID diawali dengan berbagai sosialisasi yang dilakukan melalui kegiatan budaya sehingga muncul pemahaman bersama dari berbagai elemen masyarakat. Beberapa warga menganggap SID menjadi program bersama yang dapat dilihat dari keaktivan masyarakat dalam menyampaikan informasi melalui sms gateway.

Dengan adanya pemahaman yang sama tentang manfaat program SID maka sesuai dengan konsep yang ada yaitu; Pertama, kebersamaan, partisipasi tumbuh melalui konsensus dan kesamaan visi, cita-cita, harapan, tujuan dan saling 
membutuhkan satu dengan yang lainnya. Kedua, tumbuh dari bawah, partisipasi bukan sesuatu yang dipaksakan dari atas ke bawah "top down" atau dikendalikan oleh individu atau kelompok melalui mekanisme kekuasaan. Partisipasi tumbuh berdasarkan kesadaran dan kebutuhan yang dirasakan oleh masyarakat. Terakhir, kepercayaan dan keterbukaan, partisipasi akan dapat ditumbuhkan atas dasar saling percaya dan keterbukaan (Wahyudin Sumpena, 2004:60).

Untuk program SID, faktor-faktor yang mendorong adanya partisipasi yakni: kebersamaan. Masyarakat secara bersama-sama terlibat dalam pengisian data dan pengaktivan program SID. Keinginan adanya program SID adalah keinginan yang munculnya dari desa bukan program yang didesakkan dari sehingga program ini memang tumbuh dari bawah. Selain itu, karena program ini merupakan inisiatif dari masyarakat tentunya muncul adanya kepercayaan dan keterbukaan.

Partisipasi sangat menentukan program SID seperti yang disampaikan Wilhelm Wau (2012), bahwa dalam mengembangkan sistem informasi desa yang berbasis komunitas, partisipasi merupakan salah satu unsur penting untuk keberhasilan program ini. Partisipasi diharapkan dimulai dari tahap perencanaan, perumusan masalah, pengambilan keputusan, pengembangan kapasitas, pemanfaatan sampai pada tahap evaluasi dan monitoring.

\section{Manfaat Sistem Informasi Desa}

Keberlangsungan SID tentunya sangat tergantung dari manfaat yang dirasakan masyarakat terhadap program tersebut. Seperti yang disampaikan oleh CRI, konsep SID merupakan informasi yang diimplementasikan melalui prangkat teknologi informasi dan aplikasi perangkat lunak yang dioperasikan oleh perangkat desa. Sistem informasi ini dibangun dengan berbasis komputer dan web sehingga informasi ini dapat diakses oleh warga. Lisensi SID dikembangkan dalam platform sistem perangkat lunak bebas dan terbuka (free and open source software) yang berarti dapat digunaka, disalin, didistribusikan, ditingkatkan kinerjanya, dimodifikasi sesuai dengan kebutuhan (Wilhem Wau: 2012).

Keberadaan SID menurut Combine Resource Institute (Wilhem Wau: 2012) didasarkan beberapa manfaat; (1) Untuk perencanaan pembangunan, dalam perencanaan pembangunan menghasilkan rangkaian proses pengambilan keputusan melalui Musrenbang (Musyawarah Perencanaan Pembangunan). Dengan adanya sistem informasi desa, maka desa memiliki pusat data yang dapat digunakan untuk pengambilan keputusan dalam Musyawarah Perencanaan Pembangunan Desa (Musrenbangdesa), (2) Untuk keterbukaan informasi, sistem informasi desa telah membuka budaya-budaya transparansi informasi yang selama ini tampak tertutup. Dengan adanya SID maka terjadi keterbukaan informasi yang memungkinkan peran dan status bukan lagi penghambat dalam berkomunikasi,

(3) Untuk pendataan kemiskinan, dengan model partisipatif maka memungkinkan dilakukan pendataan kemiskinan di tingkat desa yang lebih akurat, (4) Untuk pelayanan publik, dengan adanya SID maka data-data kependudukan, data ke- uangan desa maupun sumberdaya desa akan tersimpan dalam database. Hal ini memungkinkan desa memberikan pelayanan yang lebih akuratdancepatuntuk permohonan suratsurat dari warga. 
Sesuai dengan konsep Wilhem Wau (2012), keberadaan program SID di Desa Terong sudah dapat memberikan manfaat dalam; (1) perencanaan pembangunan, dalam perencanaan pembangunan menghasilkan rangkaian proses pengambilan keputusan melalui Musrenbang (Musyawarah Perencanaan Pembangunan). Dengan adanya sistem informasi desa, maka desa memiliki pusat data yang dapat digunakan untuk pengambilan keputusan dalam Musyawarah Perencanaan Pembangunan Desa (Musrenbangdesa), (2) Untuk keterbukaan informasi, sistem informasi desa telah membuka informasi desa yang selama ini tampak tertutup. Dengan adanya SID maka terjadi keterbukaan informasi yang memungkinkan peran dan status bukan lagi penghambat dalam berkomunikasi; (3) Untuk pelayanan publik, dengan adanya SID maka datadata kependudukan, data keuangan desa maupun sumberdaya desa akan tersimpan dalam database. Hal ini memungkinkan desa memberikan pelayanan yang lebih akurat dan cepat untuk permohonan surat-surat dari warga.

Salah satu yang sulit dilakukan untuk program SID adalah pendataan masyarakat miskin secara akurat karena masyarakat desa enggan untuk menyampaikan secara terbuka. Bagi masyarakat data kemiskinan masyarakat tidak selayaknya ditampilkan dalam SID, karena SID terbaca secara umum/ publik. Selain itu kebijakan-kebijakan yang terkait dengan data kemiskinan masyarakat misalnya, program Raskin, BLSM, Jamkesmas pemerintah pusat tidak berkonsultasi dengan desa. Desa hanya sekedar menerima data dari atas. Hal ini sungguh disesalkan oleh pemerintah desa karena data yang dipakai oleh pemerintah sudah jauh berbeda dengan kondisi yang sekarang. Penyampaian program bantuan didasarkan data yang sudah lama sehingga terkadang program pemerintah untuk memberikan kesejahateraan masyarakat tidak mengenai sasaran. Aparat desa pun tidak berani untuk mengambil inisiatif menggunakan data dari SID yang valid karena kekhawatiran akan mengalami kesulitan dalam pelaporan program tersebut.

\section{Simpulan}

Program Sistem Informasi Desa di Desa Terong merupakan program yang tumbuh dari kebutuhan dan keinginan masyarakat desa. Dengan adanya kepentingan yang sama maka partisipasi dari masyarakat akan mudah dimunculkan. Dengan adanya partisipasi dari masyarakat maka keberlanjutan suatu program akan lebih mudah terlaksana.

Program SID yang diinisiasi dari masyarakat merupakan sinergi kerjasama antara masyarakat, aparat desa dan CRI. Program yang merupakan inisiasi bersama sebaiknya dapat $\mathrm{t}$ diakomodir oleh pemerintah. Sehingga pemerintah dalam menyampaikan kebijakan dari mereka juga berbasis dari kebutuhan dan kepentingan masyarakat yang dituju. Sehingga tujuan dan target dari program kebijakan akan dapat mencapai sasaran.

Keberlangsungan program SID sangat tergantung dari manfaat program tersebut bagi masyarakat. Saat ini teknologi informasi semakin cepat berkembang dan fakta yang ada dengan pemanfaatan teknologi informasi maka akan memberikan manfaat dalam berbagai hal termasuk untuk desa. Bila keberadaan suatu program ini sebagai kebutuhan maka keberlangsungan 
program SID juga semakin baik. Terkadang program yang disampaiakn pemerintah hanya dilakukan untuk mengejar target terpenuhi kegiatan tanpa memikirkan keberlanjutan program akan mengakibatkan program menjadi sulit untuk berlanjut.

\section{Daftar Pustaka}

Bryant, Coralie dan White, Louise G. ,1987, Manajemen Pembangunan Berkembang. Jakarta: LP3ES.

Denzin, K, Norman. \& Lincoln, Yvonna S.. 2009. Handbook of Qualitative Research. Penerjemah Dariyatno, Badrus Samsul dkk. Pustaka Pelajar: Yogyakarta.

Eko, Sutoro.. 2005. Pembaharuan Desa. APMD Press: Yogyakarta.

Isbandi. . 2005 "Komunikasi dan Partisipasi Warga Perantau dalam Pemberdayaan Masyarakat". Jurnal Ilmu Komunikasi. Vol. 3. No. 2 (147157).

Jahja, Ranggoaini, Haryana dkk. 2012. Sistem Informasi Desa Sistem Informasi dan Data untuk.

Pembaharuan Desa. Combine Resource Institution: Yogyakarta.

Moleong, Lexy J. 2005. Metodologi Penelitian Kualitatif (Edisi Revisi). PT Remadja Rosdakarya: Bandung.

McLuhan, Marshall. 1994. Understanding Media: The Extension of Man. London: The MIT Press.

Rusmala, Candra. 2005. "Memaknai kembali Partisipasi masyarakat : Bekerja Bersama
Kelompok" dalam Dimensi-Dimensi Masa- lah Sosial dan Pemberdayaan Masyarakat. Yogyakarta: APMD Press.

Rusmala, Candra dan Widati. 2004.Modul Materi Kuliah Partisipasi Masyarakat. Yogyakarta: STPMD “APMD”.

Rudito, Bambang dan Famiola. 2009.

Social Mapping. Metode Pemetaan Sosial. Bandung: Rekayasa Sains.

Sulisyowati, Fadjarini, Wuryantono, Theodorus dan Astuti Dian. “: 2005. Ruang Publik Desa Yogyakarta: APMD Press.

Ruang Partisipasi yang Kosong" dalam Komunikasi Pembedayaan. Yogyakarta: APMD Press.

Sumpeno, Wahyudin. 2004. Sekolah Masyarakat, Menerapkan Rapid Training Design dalam Membangun Kapasitas. Jakarta: Chatolic Relief Service.

Supeno,Eko. 2005. PartisipasiMasyarakat dalam Proses Pembangunan dan Upaya Mewujudkannya". Jurnal Masyarakat Kebudayaan dan Politik. Volume 9. No. 2 (1-5).

Sutopo, H. B. 2006. Metodologi Penelitian Kualitatif. UNS Press: Solo.

Wau, Wilhem. 2012. Sistem Informasi Desa Mengelola Sumber Daya Lokal Untuk Kemandirian Bangsa. Combine Resource Institution: Yogyakarta

Wahyono, S. Bayu. 2011. “Optimalisasi Program Desa Informasi Melalui Penguatan Kelembagaan". IPTEKKom Jurnal Penelitian Komunikasi dan Informatika. Balai pengkajian dan Pengembangan Komunikasi dan informastika (BPPKI): Yogyakarta 